26. Satchell, J. E., K. Martin, and R. V. Krishnamoorthy. 1984. Stimulation of microbial phosphatase production by earthworm activity. Soil Biol. Biochem. 16(2):195.

27. Singh, C. P., Y. P. Singh, and M. Singh. 1987. Effect of different carbonaceous compounds on the transformation of soil nutrients. II. Immobilization and mineralization of phosphorus. Biol. Agric. Hort. 4:301-307.

28. Sposito, G. 1984. The Surface Chemistry of Soils. Oxford University Press. 223 pp.

29. Swaider, J. M., and R. D. Morse. 1984. Influence of organic amendments on solution phosphorus requirements for vegetables in minespoil. J. Amer. Soc. Hort. Sci. 109:150-155.
30. Truog, E. 1948. Lime in relation to availability of plant nutrients. Soil Sci. 65:1-7.

31. U.S.D.A. 1978. Improving Soils with Organic Wastes. U.S. Government Printing Office. 157 pp.

32. Van Gansen, P. S. 1962. Structures and functions of the digestive tract of the lumbricid Eisenia foetida. J. Microscopy 1:363-366.

33. Vendekamp, J. H., F. W. T. Penning De Vries, and J. T. M. Kiit. 1986. Phosphorus redistribution in maize plants (Zea mays L.) in relation to the nitrogen supply. J. Agron. Crop Sci. 157:208-214.

34. Vleeschauwer, D. D., and R. Lal. 1981. Prop- erties of worm casts under tropical forest regrowth. Soil Sci. 132(2):175-181.

35. Wild, A. 1950. The retention of phosphate by soil. A review. J. Soil Sci. 1:221-238.

36. Williams, R. F. 1948. The effects of phosphorus supply on the rates of intake of phosphorus and nitrogen and upon certain aspects of phosphorus metabolism in gramineous plants. Austr. J. Sci. Res. (Series B). 1:333-341.

37. Woodruff, J. R., and E. J. Kamprath. 1965. Phosphate adsorption maximum as measured by the Langmuir isotherm and its relationship to phosphorus availability. Soil Sci. Soc. Amer. Proc. 29:148-150.

\title{
LETTERS
}

\section{Outlines, complexity, and breadth of sustainability}

Having been to many agricultural gatherings where the topic of "sustainable agriculture" was addressed, I have an impression that the mainstream agriculture establishment still believes all is well and that we can fix agriculture's problems by simply trying out a few reduced chemical experiments, a few comparisons with conventional methods, and that is "sustainable agriculture." The sustainability of agriculture thus has been reduced to the question of chemical use.

Reduction and elimination of petrochemicals is a very important aspect of a healthy agriculture, and we do need to search for agronomic practices that enhance soil life. However, even if all farms become chemical free, we will be far from a sustainable agriculture unless we seriously address the following basic questions, concerns, and goals:

Renewable energy. Currently, we are converting barrels of oil to bushels of grain; our modern agriculture is running entirely on rapidly depleting oil and gas, and our so-called "safe food supply" is extremely vulnerable. No agriculture can be sustained unless it runs on renewable energy. What are we doing in our research to address and seek ways of kicking the petrofarming habits? What are we doing to promote a fresh, locally grown food economy, to invest in the local community, as well as to avoid processing, packaging, and transportation?

Rural communities. More than 200,000 farms went bankrupt in the 1980's alone. By almost any measure, our rural communities are declining. Are the land-grant universities, the USDA, and state departments of agriculture building and revitalizing communities? Are we addressing the root causes of rural decline? Those of us who are seeking sustainability in agriculture see agriculture and rural communities rooted in one another and inseparable. We must invest in and build on our rural heritage.

Soil and water conservation. Neither agriculture nor people can survive if we continue to waste soil and pollute our water. We have more soil erosion now than we did during the Dust Bowl era. How can we reverse this trend?

Health questions. We, the public, are concerned about pesticide residue on our food, chemicals in our drinking water, antibiotics and hormones in our food, and risks to the farmer. The connection between our health and our agriculture is ignored entirely by experts who, with their usual self-assured tone, tell us all is safe and that, since there is no proof it is unsafe, do not worry. Since people's lives and the health of the biosphere are at stake, why shouldn't the burden of proof that our food is safe rest on those who claim so?

Agricultural policies. In order for agriculture to be economically viable, environmentally sound, and socially just, we need local, national, and international policies that help rather than work against these goals. Our universities should be a debating ground for these policies. How are agricultural policies affecting the people and agriculture?

True economics. All things that the "economy" depends on come from the Earth. Our current economic thinking does not take the Earth and the future generations into account. In a true economy, conservation is always economical and degradation extremely costly. We need to transform our fake economics so that it will truly reflect our dealings with the Earth.

Education, research, and extension. A shift towards a sustainable agriculture necessarily requires a fundamental change in our short-term, departmentalized research and teaching. It also requires direct farmer-researcher, farmer-farmer, and farmer-student exchange of ideas and practices. In order to make the university research more relevant to real problems of agriculture, colleges of agriculture must be mandated to run a farm successfully and profitably. That process can transform us and our efforts in education, research, and extension in unforeseen 
ways.

Urban responsibility. The 98 percent of Americans who are urban residents cannot lead wasteful lifestyles with polluting industries and expect the farmers to run chemical-free farms and be stewards of the land. Urban generated pollution will continue to impact agriculture negatively. What are we doing in the cities to conserve energy, recycle, and prevent air and water pollution?

Multi-national corporations and rural communities. How are the multinational corporations affecting agriculture, people, rural communities, and the land in the U.S. and abroad? Can we have a healthy agriculture when a handful of corporations control the entire market in agriculture?
A land ethic. Our ethics prompt us to care for other individuals and the community; our ethics rule out doing things that harm the community. Aldo Leopold described a land ethic in $A$ Sand County Almanac, "The land ethic simply enlarges the boundaries of the community to include soils, waters, plants, and animals, or collectively the land. That land is a community is the basic concept of ecology, but that land is to be loved and respected is an extension of ethics."

Generally, no concept of a land ethic seems to prevail among agriculturalists, universities, and our entire educational system. Aldo Leopold believed "conservation is getting nowhere be- cause it is incompatible with our Abrahamic concept of land. We abuse land because we regard it as a commodity belonging to us. When we see land as a community to which we belong, we may begin to use it with love and respect." What can we do to integrate a land ethic into our education, agriculture, and lives?

All of these concerns and questions must be central to our search towards a sustainable agriculture.

Kamyar Enshayan, Ph.D.

Sustainable Agriculture

Program

The Ohio State University

Columbus, $\mathrm{OH} 43210-1220$

\section{BOOK REVIEWS}

The Ecology of the Nitrogen Cycle. 1987. By Janet I. Sprent. Cambridge University Press, New York, New York. 151 pp. $\$ 39.50$, cloth; $\$ 14.95$ paper.

Janet Sprent has written a small volume which might have been entitled "The Nitrogen Cycle in a Nutshell." Despite its brevity (its 151 pages include references and an index), it is remarkably informative and comprehensive, containing 243 references to relevant research. The book is aimed at advanced undergraduates, early graduate students, and researchers in allied areas, particularly agronomy and ecology. It should be extremely useful to this group. It should also be of interest to the scientifically informed portion of the general public, especially those concerned with environmental issues.

The first part of the book, "General Features of the Nitrogen Cycle," gives background information about the nitrogen cycle. This section includes a description of the energetics and biochemical pathways of the major reactions of the nitrogen cycle, both biologic and abiologic. A discussion of the interrelation between the nitrogen cycle and other elemental cycles is included. The central importance of the interaction between the carbon and nitrogen cycles is appropriately emphasized. Past and present constraints on the nitrogen cycle and environmental effects on nitrogen transformations are also discussed.

Because of its brevity, the first section of the book may strike some readers as densely written. The information in the tables and figures is correct, but the reasons may not be obvious. Readers who want to go beyond taking the author's word for the accuracy of the material will often have to consult the references she cites to find the omitted explanations.

The general first section of the book provides both the information needed for and the point of view taken in the second section, which consists of case histories from particular environments, including arid and semi-arid ecosystems, tundra, forests, peat soils, areas subject to flooding, aquatic ecosystems, agricultural areas, and forests. A description of the effect of burning fossil fuels on the nitrogen cycle is included.
This book is well written by an outstanding authority in the field and is recommended both to readers who are tangentially interested in the operation of the nitrogen cycle and as an introduction for readers who are interested in studying the nitrogen cycle in greater depth.--Georgia Shearer, Department of Biology, Washington University, St. Louis, $M O$.

\section{LETTERS TO THE EDITOR INVITED}

The AJAA welcomes letters, short or long, commenting on articles in this journal or sharing ideas likely to be of interest to other AJAA readers. Since our space is limited, we do reserve the right not to publish all letters or, at times; to publish only excerpts from them. To take part in this exchange of ideas, write to: Editor, AJAA, 9200 Edmonston Road, Suite 117, Greenbelt, MD 20770. 